\title{
Utilizing Teacher Leadership as a Catalyst for Change in Schools
}

\author{
Raymond J. Ankrum (Corresponding author) \\ School of Education \\ Pace University, New York, NY, USA \\ E-mail: rankrum@pace.edu
}

Received: March 8, 2016 Accepted: March 28, 2016 Published: March 30, 2016

doi:10.5296/jei.v2i1.9154 URL: http://dx.doi.org/10.5296/jei.v2i1.9154

\begin{abstract}
School leaders are constantly trying to find alternative ways to leverage and explore teacher leadership potential in their school building(s). Teachers leaders that are willing to go above and beyond their general duties. Teacher leaders are the type of educators that fall under the motif of potentially taking on additive responsibilities that will help to improve the school community. This paper looks at ways to leverage relationships between teacher leaders and school leaders in order to get maximum output from school staff. By infusing shared leadership in the school community, responsibility and accountability becomes a shared belief, that can be utilized as a catalyst for change in the school community.
\end{abstract}

Keywords: Distributed leadership, Teacher leadership, Professional learning communities

\section{Introduction}

Terry (2000) states, "Throughout the educational institutions across America, principal leadership is being scrutinized by the people who are being led, the teachers. Traditionally principal leadership has been looked upon as being authoritarian. It has evolved into a type of leadership described as being coercive, manipulative, and controlling. These negative tactics have proven counter-productive."

Moreover, "according to Bennis (1989), "leadership is the wise use of power", but as stated by Reitzug (1991), traditionally, principal leadership has not demonstrated wise use of power." We must separate ourselves from this way of thinking. We must do outside of the box thinking to make sure that we are tapping into the skillsets of all of the stakeholders in the school setting. Therefore, "it is essential that a principal create an environment conducive to empowerment, demonstrates empowerment ideals, encourages all endeavors toward empowerment, and applauds all empowerment successes.” (Terry, 2000) 


\section{Macrothink}

Koppich (2001) states teacher leadership can improve teacher retention, strengthen the teaching profession, build the capacity of school leaders, and facilitate innovative advances to the structure of school staffing. York-Barr and Duke (2004) state, by clearly and regularly communicating with and engaging fellow teachers in dialogue about improving teaching and learning, teacher leaders build a school culture of trust, which leads to improvement in instructional practice and ultimately positively affects student achievement. Thus, "teachers' pedagogical competence to affect student learning through their instructional practices is closely tied to their assumptions about whether students can learn and to their ability to modify their instructional practice" (Printy, 2008, p. 198). Ross and Bruce (2007) note that when teachers with high efficacy face struggling students in danger of failure, they exert greater effort, rather than surrendering by deeming that the causes for failure are beyond their control.

According to Danielson (2006) and Killion and Harrison (2006), informal teacher-leaders are those individuals who:

1) Take initiative among faculty members.

2) Mobilize people for a common purpose.

3) Monitor the progress of other teachers.

4) Act as a liaison between faculty and administration.

5) Share their knowledge and skill of the practice with others.

\section{Literature Review/Theoretical Underpinning}

\subsection{Distributive Leadership}

Distributed leadership theorists describe leadership as being 'stretched out' over a variety of stakeholders within a school and argue that: 'leadership practice is constituted-defined or constructed-in the interaction of leaders, followers, and their situation in the execution of particular leadership tasks' (Spillane et al. 2004, p.10). Distributed leadership is often defined as decision-making and influential practices executed by numerous individuals at multiple levels in an organization, instead of a singular leader at the top of a hierarchical system (Leithwood et al. 2009).

Harris (2007) advocates the use of distributed leadership in schools for two main reasons: firstly, it has the authority to unshackle schools from the rigid leadership structures, and secondly, it has the potential to yoke leadership practices more closely to teaching and learning (p. 29). According to Gunter et al. (2013) after many years of rigorous engagement with empirical studies, Peter Gronn consequently concluded that the best way to think about leadership is through 'hybridity' where a formal position is not rejected in favor of notions related to distributed leadership. Both formal and informal leaders should always be engaged in leadership activities. It is, however, crucial for the formal leaders to unswervingly influence informal leaders, mainly through building a supportive environment (Harris, 2007).

MacBeath (2005) develops a taxonomy of distributed leadership that identifies different ways 
in which the transfer of leadership from the top downwards may occur: formally (through roles/job description); pragmatically (through necessity or ad hoc delegation); strategically (by appointment); and incrementally (devolving greater responsibility as capacity is demonstrated).

However, while the focus of this argument is a theoretical one, implicit in it is the contention that, for schools to truly lead system-wide change, the collective leadership potential of all teachers, and indeed the wider school work force and students, must be recognized and developed (Hargreaves, 2011; Hopkins, 2006) and for reform to be system wide and system deep (Hopkins, 2006). It is important to acknowledge those critical voices that point to the connection between teacher and distributed leadership discourse and policy and the regulatory and performative regimes that are dominant in many education systems (Ball, 2010; Fitzgerald \& Gunter, 2008; Hartley, 2010).

\subsection{Teacher Leadership}

Scholars define teacher leadership (TL) to include formal roles and informal roles such as leader of professional learning communities (PLC) or peer coach (Liston et al., 2008). TL is an umbrella term for work that encompasses three developmental foci among practicing teachers: (a) individual development; (b) collaboration; and (c) organizational development. Recent organizational leadership models recognize that leadership must emerge from many individuals within an organization rather than being vested in a small number of formally recognized leaders. Applied to schools, this model of organizational leadership provided an impetus for the emergence of TL.

York-Barr and Duke (2004) defined teacher leadership as: 'the process by which teachers, individually or collectively, influence their colleagues, principals, and other members of school communities to improve teaching and learning practices with the aim of increased student learning and achievement' (pp. 287-288). The research also noted that, beyond these dispositions, teacher leaders have backgrounds as accomplished teachers, which demonstrates their expertise and gives them credibility.

Danielson (2007) was more specific and pointed to formal and informal leadership roles as a way for experienced teachers to exert influence over the operations of their school without entering administration. Both authors agreed that working with colleagues is profoundly different from working with students (Danielson, 2007) and that learning to function as leader requires nothing less than a profound identity shift for contemporary classroom teachers' (Bowman, 2004, p. 187). Ross et al. (2011) concur that making the development of teacher leaders a priority in education systems concerned with reform will result in those systems achieving in school improvement, better student learning outcomes, enhanced teacher learning and increased staff retention.

First, professional development is required to develop teachers as leaders and to assist administrators in conceptualizing their roles as 'head learners' (Yendol-Hoppey \& Dana, 2010) who share leadership. Effectively done, professional development serves as the impetus for the professionalization of teaching and the development of teachers' leadership 
skills toward influencing and improving the practice of their colleagues (Murphy, 2005). Teachers that become leaders facilitate effective, school-based professional development for their teacher colleagues by leading communities of practice that collectively examine and improve teaching practice through on going inquiry (for example, Smeets \& Ponte, 2009). "Like many authors, Danielson (2007) pointed out that teacher leadership can be both formal (i.e. instructional coaches and department chairs) and informal (i.e. taking initiative to solve a program). Drawing on the work of Michael Fullan, Danielson (2007) further explained: 'effective teacher leaders exhibit important skills, values, and dispositions' in that they are 'open-minded and respectful of others' views. They display optimism and enthusiasm, confidence, and decisiveness' (p. 16)."

\subsection{Professional Learning Communities}

The term 'professional learning communities' usually refers to teachers 'critically interrogating their practice in ongoing, reflective and collaborative ways' in order to promote and enhance student learning (Stoll \& Louis, 2008). As Resnick (2010) highlights, collaborative routines among teachers are an important component in securing improved student learning outcomes. These collaborative routines have been described in various ways but are best described as 'networked learning communities' or 'professional learning communities' (Stoll \& Louis, 2007). Within such communities, practice is developed and refined through the collaboration of 'groups of people who share a concern, a set of problems, or a passion about a topic, and who deepen their knowledge and expertise by interacting on an ongoing basis' (Wenger, 2002).

Katz, Earl, and Ben Jafaar (2009) identify four key characteristics of successful professional learning communities: (1) they have a challenging focus; (2) they create productive relationships through trust; (3) they collaborate for joint benefit, which requires 'moderate professional conflict', although not personal conflict; and (4) they engage in rigorous enquiry. It reinforces that PLCs can stimulate and spread innovation about learning and teaching practices, as well as to raise collective and individual professional performance (Hopkins, 2006).

McLaughlin and Talbert (2008) distinguish between teacher communities that maintain traditional practices and the status quo, and those that reinvent and reinvigorate practice. Improvement through professional learning communities is only possible if teachers collaborate and focus on the 'real work' of improving learning and teaching (Harris \& Jones, 2009). Fullan (2009) talks about the importance of creating 'cultures for learning' that underlines the importance of people learning from each other and being collectively committed to improvement.

\section{Methodology/Participants}

The researcher is an emerging scholar-practitioner who has participated in several models of cohort learning. In 2010 the researcher participated in the Summer Principal's Academy (SPA), a cohort of emerging school leaders being trained to become principals in various regions of the United States. In 2015-16, the researcher participated in the National 
Superintendents Academy, a cohort model that prepares members on what to expect as Superintendents of school systems throughout the United States. The researcher reached out to the various cohorts of learners, introduced himself as a member of their prospective cohort learning models, and asked for participation and completion of a survey linked centered around teacher leadership. Several leaders followed up after filling out to the survey expressing their interest in learning more about how this research could advance their own pedagogical practice.

\subsection{Apparatus and Materials}

The researcher sent out an introductory email explaining the research, stated explicitly that the survey was voluntary, and expressed gratitude and admiration for those that would be able to find time to participate and complete the survey instrument. In total forty (40/175) $22.8 \%$ of participants responded to the survey. The race, demographics, socioeconomic status of the survey participants are unknown to the researcher. The two respective cohort cadres from Teachers College Summer Principals Academy (SPA), and the cohort from the National Superintendent Academy (NSA) had a total of 175 leaders, ranging from Assistant Principals to Central Office Leaders, to Superintendents of Schools. The Likert survey administered was composed of 5 responses ranging from 1-5, 1 representing strong disagreement, and 4-5 representing strong agreement respectively. The survey was created using google forms. Google forms also provides its user data collection, as well as data analysis of the data collected.

\subsection{Procedure}

The administered tool was a Likert Survey, consisting of five questions centered on teacher-leadership, its role in culture transformation, improving professional development, and establishing professional learning communities that improve pedagogical practice. The survey link was sent to several cohorts of Teachers College Columbia University's Summer Principals Program (SPA), and to one cohort of the National Superintendents Academy (NSA). Each participant was notified that their participation was voluntary in nature, and that their participation was extremely appreciated (See Appendix 1).

\subsection{Discussion}

Muijs and Harris (2003) framed teacher leadership as containing four aspects: (1) brokering role of teacher leaders to ensure that links within and across schools are in place and that opportunities for meaningful development among teachers are maximized; (2) participative leadership role of teacher leaders where they work collegially with other teachers to encourage the examination of instructional practices; (3) mediating role of teacher leaders where they become sources of instructional expertise and information; and (4) teacher leaders' role in forging close relationships with individual teachers through mutual learning.

Muijs and Harris (2007) further state that teacher leadership may be a key to improving teaching and learning in schools if teachers are praised as decision-makers, field experts, team leaders, initiators or mentors improve the quality of classroom instruction in schools where healthy and positive relationships among teachers and principals flourish. Teacher 
leadership means a role shift for teachers from followership to leadership, and teacher leaders are expected to function effectively in varied school processes such as decision-making on instructional issues, leading teams or participating in advisory boards (Grant, 2006). As also stressed by Katzenmeyer and Moller (2009), teachers tend to develop their teaching skills and improve the quality of classroom instruction in schools where healthy and positive relationships among teachers and principals flourish.

Harris (2003) asserts that teacher leaders need to be developed not only in terms of teaching knowledge but also leadership roles in order to increase their confidence in leading others. The potential of teacher leadership in bringing about improvements in teacher effectiveness is highly significant taking into consideration that the closer leaders are to teaching and learning, the more they are likely to make a difference to students (Robinson, 2007).

\subsection{Hypothesis}

In conducting this research, I expected (a) the results to conclude teacher leaders play an important role in changing the climate of a school; (b) teacher leader professional development is impactful to the teaching staff; (c) teacher leaders provide valuable guidance and support to the teaching staff; (d) teacher leaders increase the level of rigor provided by the teaching staff; and (e) teacher leader led professional development does in fact improve instruction in schools.

\section{Results/Findings}

Teacher Leaders are catalysts for change in schools. This research delves into exactly how meaningful teacher leaders are to the process of change in schools. Teacher leaders often times go unacknowledged because they don't have titles, but titles do not make their impact any less meaningful. Survey question one analyzed the role teacher leaders play in enacting change in the culture of schools. $90 \%$ of participants highly agreed that teacher leaders play an instrumental role in changing the culture of a school. Survey question two analyzed the impact of teacher led professional development and its impact. $75.5 \%$ of participants highly agreed that teacher lead professional development is meaningful to the teaching staff. Survey question three measured if teacher leaders provided guidance and support to the rest of the teaching staff. $93 \%$ of participants highly agreed that teacher leaders provide guidance and support to the rest of the teaching staff. Question four surveyed if teacher leaders increase the level of rigor in classrooms. $70 \%$ of participants highly agreed that teacher leaders increase the rigor in classrooms. Question five analyzed if teacher led peer observations were meaningful. $90 \%$ of participants highly agreed that teacher leader led peer observations were impactful to the teaching staff. It's important to note, that no participant selected anything less than three on the likert scale. The researcher chose to highlight highly agreed rather than focus on the fact that $100 \%$ of the participants agreed on the survey items.

\section{Hypothesis 1-5 Discussion}

In analyzing the researcher's hypothesis (a) the results will conclude teacher leaders play an important role in changing the climate of a school; This hypothesis was upheld by $90 \%$ of participants highly agreeing that the role of teacher leaders has an insurmountable impact on 
the culture of schools. (b) teacher leader professional development is impactful to the teaching staff; This hypothesis was also confirmed with over $75 \%$ of participants highly agreeing that teacher leader led PD was impactful. My wonder is if the instructional leader or superintendent responders feel as if experts on the topic offer better options for professional development. (c) teacher leaders provide valuable guidance and support to the teaching staff; This hypothesis was also confirmed with $93 \%$ of participants highly agreeing that teacher leaders provide valuable support and guidance to the teaching staff. (d) teacher leaders increase the level of rigor provided by the teaching staff; This hypothesis was confirmed with $70 \%$ of participants highly agreeing that rigor was increase due to teacher leaders. This was the lowest amount in participants highly agreeing, and could very well be the source of more investigation on behalf of the researcher. Finally, (e) teacher leader led professional development does in fact improve instruction in schools; This hypothesis was confirmed with $90 \%$ of participants highly agreeing that teacher led peer observations were impactful.

\section{Study Limitations}

One such limitation is the actual usage of the Likert Survey tool. Utilizing surveys as collections of data sometimes limit the depth in which the respondents can elaborate on the subject. Possibly adding a component to the survey that allows participants an open-ended forum on the direction that they would like to see teacher-leadership emerge. The researcher wanted to keep the questions short and concise to ensure participation from participants, while maintaining a high level of respect for the time that it takes to complete surveys. Other limitations include but are not limited to the amount of respondents to the actual survey. The survey could have been incentivized to perhaps win a prize to encourage more participation from the participants. The researcher could have also used a randomized control type study to better test the hypotheses that were introduced in the research.

\section{Further Research}

Angell and DeHart (2011) found that that while many teachers have the desire and motivation to lead, they didn't always have the opportunities, concluding that principals need to understand what teacher leadership looks like beyond the classroom. The literature on teacher leadership is indeed relatively rich with claims on the potential and desired effects of teacher leadership and relatively sparse with evidence of such effects, especially at the levels of classroom practice and student learning (York-Barr \& Duke, 2004).

According to Barth (2001), sometimes teacher colleagues exhibit an "inhospitable" ethos to teacher leadership or believe that the teacher leader receives unmerited recognition from the administration. This sort of recognition should motivate teachers to lead from within their classrooms, and not deter their efforts to change the paradigm within schools. In essence, teacher leadership requires a change in school culture and norms and "necessitates new organizational structures and roles in schools in order to successfully meet the needs of $21 \mathrm{st}$ century learners" (Teacher Leadership Exploratory Consortium, 2011, p. 12).

As conceptions for teacher leaders continue to evolve, a spotlight is on principals who have the capacity to empower others, as opposed to initiating a system of delegation or assigning 
roles and duties (Harris, 2003). Ayers and Sommers (2009) noted, "it is leadership that an organization must have, not a single leader. In the most robust and resilient organizations, anyone can step forward to provide leadership when that individual is best positioned and best equipped" (p. xxi).

\section{Conclusion}

While there is increased emphasis on the responsibility of the principal as the instructional leader, recent analyses suggest that 'increasing teachers' involvement in the difficult task of making good decisions and introducing improved practices must be at the heart of school leadership ... there is no simple short-cut" (Seashore, Dretzke, \& Wahlstrom, 2010, p. 332). Effective school leadership is a complex, collective effort of classroom teaching, leadership at many levels, and trust among educators, parents, and students in motivating high performance (Bryk \& Schneider, 2002). Schools that exhibit "high trust" not only involve teachers in collective decision making but they are also more likely to spread reform initiatives (Louis et al., 2010). Clearly defining the roles of teacher leaders, with particular emphasis on not needing a title to lead from within is an essential component of implementing change from within schools.

Teacher leaders are an untapped resource in schools. By distributing leadership, and empowering teachers to take ownership of the school, research supports this as a way to increase the scholastic aptitude of schools. The title teacher leader does not have to exist in order for teachers to feel empowered. Teachers will do more if they are allowed to do more, and the act of teacher leader involvement is encouraged by school leadership. Further research can be done in the area of examining how to explicitly encourage teachers to accept the challenge and lead from their classrooms.

\section{References}

Angell, P. S., \& DeHart, C. A. (2011). Teacher perceptions of teacher leadership: Examining differences by experience, degree, and position. NASSP Bulletin, 95, 141-160. http://dx.doi.org/10.1177/0192636511415397

Ayers, M. B., \& Sommers, W. A. (2009). The principal's field manual. Thousand Oaks, CA: Corwin.

Ball, S. (2010). New voices, new knowledges and the new politics of educational research: the gathering of a perfect storm? European Educational Research Journal, 9(2), 124-137. http://dx.doi.org/10.2304/eerj.2010.9.2.124

Barth, R. S. (2001). Teacher leader. Phi Delta Kappan, 82, 443-449. http://dx.doi.org/10.1177/003172170108200607

Bennis, W. (1989). On becoming a leader. New York: Addison Wesley Publishing Company.

Bryk, A. S., \& Schneider, B. (2002). Trust in schools: A core resource for improvement. New York, NY: Russell Sage Foundation.

Danielson, C. (2006). Teacher leadership that strengthens professional practice. Alexandria, 
VA: Association for Supervision and Curriculum Development.

Danielson, C. (2007). The many faces of teacher leadership. Educational Leadership, 65(1), 14-19.

Fitzgerald, T., \& Gunter, H. (2008). Contesting the orthodoxy of teacher leadership. International Journal of Leadership in Education: Theory and Practice, 11(4), 331-340. http://dx.doi.org/10.1080/13603120802317883

Fullan, M. (2009). Motion Leadership. Ontario Principals Council, Toronto.

Grant, C. (2006). Emerging voices on teacher leadership: Some South African view. Educational Management Administration \& Leadership, 34(4), 511-532. http://dx.doi.org/10.1177/1741143206068215

Gunter, H., Dave, H., \& Joanna, B. (2013). Distributed leadership: A study in knowledge production. Educational Management Administration \& Leadership, 41(5), 555-580. http://dx.doi.org/10.1177/1741143213488586

Hargreaves, D. (2011). Leading a self-improving school system. Nottingham, National College for School Leadership.

Harris, A. (2003). Teacher Leadership as Distributed Leadership: Heresy, Fantasy or Possibility? School Leadership and Management, 23, 313-324. http://dx.doi.org/10.1080/1363243032000112801

Harris, A. (2007). Distributed leadership: Conceptual confusion and empirical reticence. International Journal of Leadership in Education, 10(3), 315-325. http://dx.doi.org/10.1080/13603120701257313

Harris, A., \& Jones, M. (2009). Leading learning for school effectiveness. Unpublished paper. Hartley, D. (2010). Paradigms: How far does research in distributed leadership 'stretch'? Educational Management Administration \& Leadership, 38(3), 271-285. http://dx.doi.org/10.1177/1741143209359716

Hopkins, D. (2006). Realising the potential of system reform. In H. Daniels, J. Porter, \& H. Lauder (Eds.), Companion in Education Series, Routledge Falmer. CiNii.

Hopkins, D. (2007). Every School a Great School. Maidenhead: Open University Press/McGraw Hill.

Katz, S., Earl, L., \& Ben Jaafar, S. (2009). Building and connecting learning communities: The power of networks for school improvement. Thousand Oaks, CA: Corwin.

Katzenmeyer, M., \& Moller, G. (2009). Awakening the sleeping giant. Helping teachers develop as leaders (3rd ed.). Thousand Oaks, California: Corwin.

Killion, J., \& Harrison, C. (2006). Taking the lead: New roles for teachers and school based coaches. Oxford, OH: National Staff Development Council. 
Koppich, J. (2001). Investing in teaching. Washington, DC: National Alliance of Business.

Leithwood, K., Mascall, B., Strauss, T., Sacks, R., Memon, N., \& Yashkina, A. (2009). Distributing leadership to make schools smarter: Taking the ego out of the system. Leadership and Policy in Schools, 6(1), 37-67. http://dx.doi.org/10.1080/15700760601091267

Liston, D., Borko, H., \& Whitcomb, J. (2008). The teacher educator's role in enhancing teacher quality. Journal of Teacher Education, 59(2), 111e116. http://dx.doi.org/10.1177/0022487108315581

MacBeath, J. (2005). Leadership as distributed: A matter of practice. School leadership and management, 25(4), 349-366. http://dx.doi.org/10.1080/13634230500197165

McLaughlin, M. W., \& Talbert, J. E. (2008). Building professional communities in high schools: Challenges and promising practices. In L. Stoll \& K. S. Louis (Eds.), Professional learning communities: Divergence, depth and dilemmas (pp. 151-165). Maidenhead: Open University Press and McGraw Hill Education.

Muijs, D., \& Harris, A. (2003). Teacher Leadership_Improvement through Empowerment? Educational Management and Administration, 31, 437-448. http://dx.doi.org/10.1177/0263211X030314007

Muijs, D., \& Harris, A. (2007). Teacher leadership in (in)action. Three case studies of contrasting schools. Educational Management Administration \& Leadership, 35(1), 111-134. http://dx.doi.org/10.1177/1741143207071387

Printy, S. M. (2008). Leadership for teacher learning: A community of practice perspective. Educational Administration Quarterly, 187-226. http://dx.doi.org/10.1177/0013161X07312958

Reitzug, U. C. (1991). A case study of empowering principal behavior. American Educational Research Journal, 31, 283-307. http://dx.doi.org/10.3102/00028312031002283

Resnick, L. B. (2010). Nested Learning Systems for the Thinking Curriculum. Educational Researcher, 39(3), 183-197. http://dx.doi.org/10.3102/0013189X10364671

Robinson, V. (2007). School Leadership and Student Outcomes: Identifying What Works and Why. Australian Council for Educational Leaders (ACEL). 41. October. NSW, Australia.

Ross, D. A., Adams, A., Bondy, E., Dana, N., Dodman, S., \& Swain, C. (2011). Preparing teacher leaders: Perceptions of the impact of a cohort-based job embedded, blended teacher leadership program. Teaching and Teacher Education, 27, 1213-1222. http://dx.doi.org/10.1016/j.tate.2011.06.005

Ross, J., \& Bruce, C. (2007). Professional development effects on teacher efficacy: Results of randomized field trial. Journal of Educational Research, 101(1), 50-59. http://dx.doi.org/10.3200/JOER.101.1.50-60

Seashore, L. K., Dretzke, B., \& Wahlstrom, K. (2010). How does leadership affect student 


\section{Macrothink}

achievement? Results from a national US survey. School Effectiveness and School Improvement, 21(3), 315-336. http://dx.doi.org/10.1080/09243453.2010.486586

Smeets, K., \& Ponte, P. (2009). Action research and teacher leadership. Professional Development in Education, 35(8), 175-193. http://dx.doi.org/10.1080/13674580802102102

Spillane, J. P., Halverson, R., \& Diamond, J. B. (2004). Towards a theory of leadership practice: a distributed perspective. Journal of Curriculum Studies, 36(1), 3-34. http://dx.doi.org/10.1080/0022027032000106726

Stoll, L., \& Louis, K. S. (2008). Professional learning communities: Divergence, depth and dilemmas. Maidenhead: Open University Press and McGraw Hill Education.

Stoll, L., \& Louis, K. S. (Eds.). (2007). Professional Learning Communities. Maidenhead: Open University Press.

Teacher Leadership Exploratory Consortium. (2011). Teacher leader model standards. Retrieved from http://www.teacherleaderstandards.org/downloads/TLS_Brochure_sm.pdf

Terry, M. P. (2000). Empowering Teachers as Leaders (pp. 1-8). University of Memphis.

Wenger, E., McDermott, R., \& Snyder, W. (2002). Cultivating Communities of Practice. Boston: Harvard Business School Press.

Yendol-Hoppey, D., \& Dana, N. (2010). Powerful professional development: Building expertise within the four walls of your school. Thousand Oaks, CA: Corwin Press.

York-Barr, J., \& Duke, K. (2004). What do we know about Teacher Leadership? Findings from Two Decades of Scholarship. Review of Educational Research, 94(3), 255-316. http://dx.doi.org/10.3102/00346543074003255 


\section{Appendix}

Appendix 1.

\section{Teacher Leadership Survey}

Likert Survey examining the value of TL.

* Required

$$
\text { Top of Form }
$$

Teacher leaders play an instrumental role in changing the culture of a school. *

$$
\begin{array}{lllll}
1 & 2 & 3 & 4 & 5
\end{array}
$$

Highly Disagree

Highly Agree

This is a required question

Teacher leader led professional development is impactful to the teaching staff. *

$$
\begin{array}{lllll}
1 & 2 & 3 & 4 & 5
\end{array}
$$

Highly Disagree

Highly Agree

This is a required question

Teacher leaders provide guidance and support to teachers. *

$$
\begin{array}{lllll}
1 & 2 & 3 & 4 & 5
\end{array}
$$

Highly Disagree

Highly Agree

This is a required question

Teacher leaders increase the level of rigor provided by the teaching staff. *

$$
\begin{array}{lllll}
1 & 2 & 3 & 4 & 5
\end{array}
$$

Highly Disagree

Highly Agree

This is a required question

Teacher leader led peer observations can improve instruction in schools. *

$$
\begin{array}{lllll}
1 & 2 & 3 & 4 & 5
\end{array}
$$

Highly Disagree

Highly Agree

This is a required question

\section{Bottom of Form}

Powered by

Google Forms

This form was created inside of Riverhead Charter School.

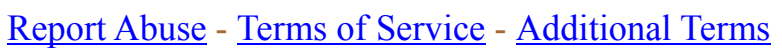

Screen reader support enabled. 
Appendix 2 .

\section{0 responses}

\section{Summary}

Teacher leaders play an instrumental role in changing the culture of a school.

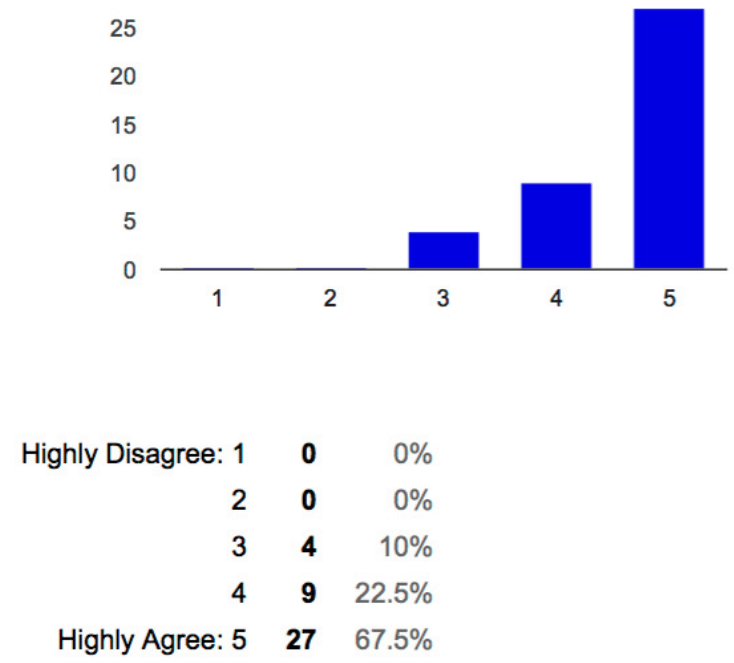

Teacher leader led professional development is impactful to the teaching staff.

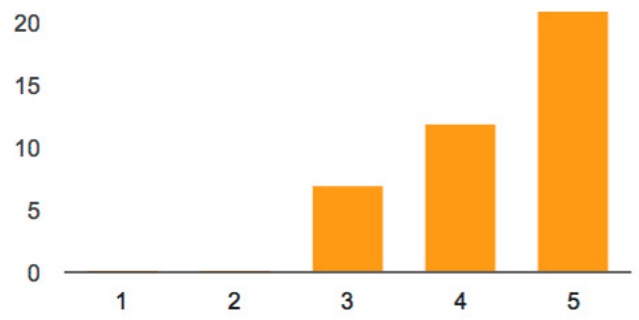


$3 / 6 / 2016$

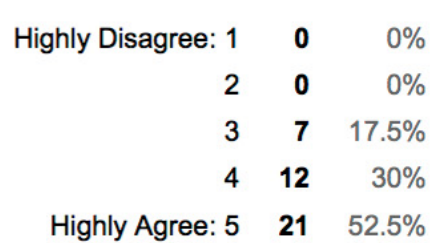

Teacher leaders provide guidance and support to teachers.

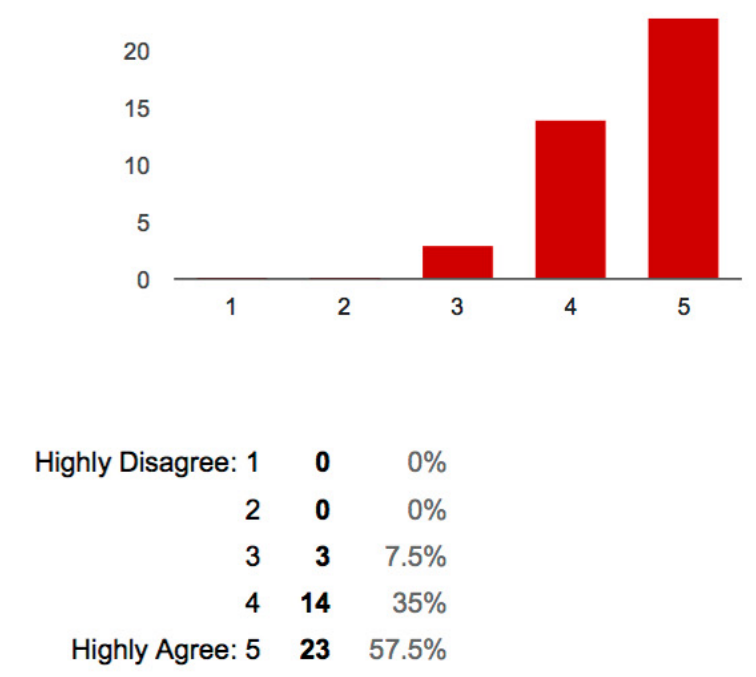

Teacher leaders increase the level of rigor provided by the teaching staff.

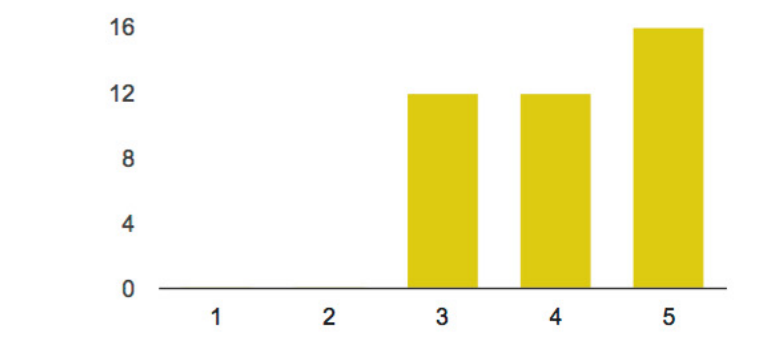

$\begin{array}{rrrr}\text { Highly Disagree: } 1 & \mathbf{0} & 0 \% \\ 2 & 0 & 0 \% \\ 3 & \mathbf{1 2} & 30 \% \\ 4 & 12 & 30 \%\end{array}$


$3 / 6 / 2016$

Highly Agree: $5 \quad 16 \quad 40 \%$

Teacher Leadership Survey - Google Forms

Teacher leader led peer observations can improve instruction in schools.

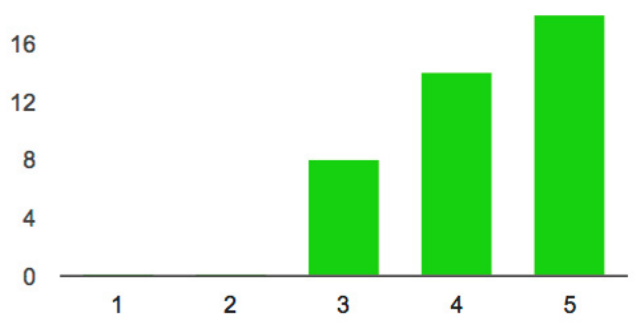

$\begin{array}{rrr}\text { Highly Disagree: } 1 & \mathbf{0} & 0 \% \\ 2 & \mathbf{0} & 0 \% \\ 3 & \mathbf{8} & 20 \% \\ 4 & \mathbf{1 4} & 35 \% \\ \text { Highly Agree: } \mathbf{5} & \mathbf{1 8} & 45 \%\end{array}$

\section{Number of daily responses}

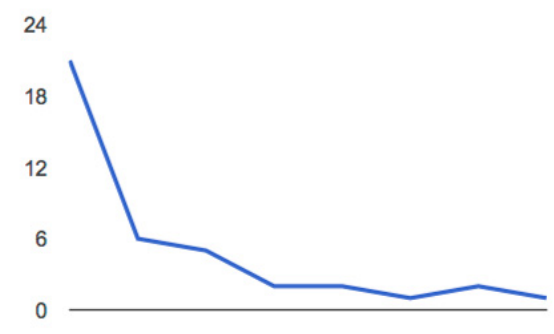

\section{Copyright Disclaimer}

Copyright for this article is retained by the author(s), with first publication rights granted to the journal.

This is an open-access article distributed under the terms and conditions of the Creative Commons Attribution license (http://creativecommons.org/licenses/by/3.0/). 